\title{
FOOD HABITS AND ONTOGENETIC DIET SHIFTS OF THE LITTER DWELLING FROG PROCERATOPHRYS BOIEI (WIED)
}

\author{
Ariovaldo A. Giaretta 1 \\ Márcio S. Araújo \\ Hermes F. de Medeiros \\ Kátia G. Facure
}

\begin{abstract}
Here is described the diet of Proceratophrys boiei (Wied, 1825), a leaf litter frog of the Atlantic Forest, and test for relationships between frog size and prey size and type. The diet was determined by stomach content analysis. In 38 frogs, was found 76 prey items belonging to 23 taxa. Insects predominate in the diet and the most frequent categories were coleopterans ( $39.4 \%$ of total volume) and orthopterans ( 25.0 $\%)$. There was a positive correlation between frog size and volume of prey taken. The most important ontogenetic shift in prey type was an increase in the consume of coleopterans and insect larvae with increasing frog size.

KEY WORDS. Amphibia, Anura, Leptodactylidae, Proceratophrys boiei, food habits, litter frog, Atlantic Forest, Brazil
\end{abstract}

When in land, frogs are thought to be opportunistic predators with their diets just reflecting the availability of food of appropriated size. The main factors influencing the diets and feeding habits of amphibians are seasonal abundance of food, size/shape constraints and ecological tolerances (DUELLMAN \& TRUEB 1986). Proceratophrys boiei (Wied, 1825) is a litter dwelling frog of the Atlantic Forest and little is known about its food habits. Its relatively large mouth (46-52\% of the total length) suggests that it preys on large items (COCHRAN 1955). Because of the pronounced difference in size between recently metamorphosed young $(18 \mathrm{~mm})$ and adults $(50-75 \mathrm{~mm})$ ontogenetic changes are expected in prey size and type, as documented for some other frog species (LABANICK 1976; CHRISTIAN 1982; LIMA \& Moreira 1993; DE BRUYN et al. 1996; Evans \& LAMPO 1996). Herein, is described the $\operatorname{diet}$ of $P$. boiei and examine whether prey size and type vary with frog size.

\section{MATERIAL AND METHODS}

The analyzed individuals of Proceratophrys boiei came from the Parque Florestal do Itapetinga $\left(23^{\circ} 15^{\prime} \mathrm{S} ; 46^{\circ} 45^{\prime} \mathrm{W}, 900-1,300 \mathrm{~m}\right.$ alt., $1,600 \mathrm{~mm}$ rain/year), municipality of Atibaia, Mantiqueira Range in the state of São Paulo, Brazil. The region is mountainous and covered by semideciduous forest. In this site, $P$. boiei is

1) Departamento de Zoologia, Instituto de Biologia, Universidade Estadual de Campinas. Caixa Postal 6109, 13083-970 Campinas, São Paulo, Brasil.

E-mail: giaretta@bestway.com.br 
found on litter most of the year, except in the dryer months (June-August). In the wetter months, they can be found in densities of 1 individual $/ 1,600 \mathrm{~m}^{2}$. The analyzed frogs were collected only in the wetter months, from December 1991 to May 1997. The stomach contents of $P$. boiei were obtained by dissection of preserved individuals and by stomach eversion of living frogs. To minimize the effects of digestion, the frogs were preserved, or stomachs everted, just after collection. In the studied species, the eversion of the stomach throughout the mouth is easy and allows us to collect all its contents without killing the frog. The living analyzed frogs showed no evidence of injury after manipulation and were released in the field. The food items were identified and grouped into categories (mainly insect orders). Individual prey items were measured with calipers $(0.05 \mathrm{~mm})$, and their volumes were estimated with the ellipsoid formula:

\section{Volume $=4 / 3 \pi$ (length/2) $($ width/2) $($ thickness $/ 2)$}

The percentages of prey volume, number, and frequency of occurrence were calculated for each category. Some very digested prey were identified but it was not possible to determine their volume. It was tested the relationship between frog size and the log-transformed volumes of the largest and smallest prey items. It was used Principal Components Analysis (PCA) (MANLY 1986) to summarize individual variation in the proportions (\% of volume) of Araneae, Coleoptera, Insect larvae, Orthoptera, and Others (insect orders contributing with less than $4 \%$ of total prey volume). It was used Sperman Rank Correlation (ZAR 1984) to test the relationship between the frogs' size and the first principal component (PC1) to search for ontogenetic shifts in prey type ( $c f$. LIMA \& MOREIRA 1993). Multivariate analysis were done with the Fitopac computer program (SHEPHERD unpublished). A voucher frog specimen is in the Museu de História Natural da Universidade Estadual de Campinas (ZUEC 9560), Campinas, São Paulo, Brazil.

\section{RESULTS}

Analyzed individuals of Proceratophrys boiei ranged from 18.2 to $73.5 \mathrm{~mm}$ in SVL. Twenty six (68.4\%) of the 38 dissected individuals and $12(31.6 \%)$ of the 38 eversed ones had no food in their stomachs. Calling males rarely had stomach contents. In the other 38 frogs were found 76 prey items belonging to 23 taxa. Prey volumes varied from 4 up to $984 \mathrm{~mm}^{3}$ and the modal number of individual prey in the stomachs was one (range 1-5). It was observed a dominance of orthopterans and coleopterans in the diet (Tab. I). Relatively large beetles and camel crickets (Henicidae), approaching $45 \%$ of the frog individual length, were found. Two adults of the froglet Eleutherodactylus parvus (adults 15-20 mm SVL) were found as prey. There was a positive correlation between the predator's size and the log-transformed volume of the largest and the smallest prey (Fig. 1). In the PC1 $(23.3 \%$ of total variance) Coleoptera had a high and positive loading, and Orthoptera had a high and negative one. There was a significant correlation between diet (PC1) and size (SVL) of $P$. boiei $\left(\mathrm{r}_{\mathrm{s}}=0.35, \mathrm{p}<0.05, \mathrm{~N}=33\right)$, indicating an ontogenetic shift in the type of prey taken. The most important change was related to an increase in the consumption of coleopterans and insect larvae with increasing frog size. 


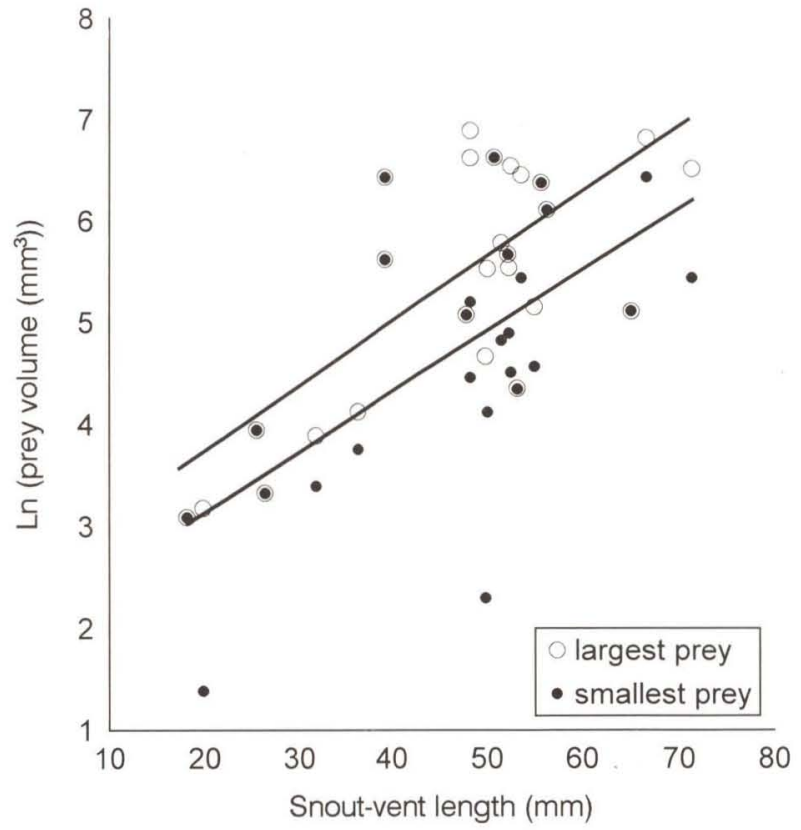

Fig. 1. Relationship between frogs and prey sizes (volume) for Proceratophrys boiei. Circles and dots are, respectively, the volumes of the largest and smallest prey found in each stomach. The top line represents the largest prey $(r=0.748, p<0.001, N=26$ frogs $)$; the bottom the smallest $(r=0.635, p<0.001, N=26$ frogs $)$.

Table I. Categories of prey and their relative importance in the diet of Proceratophrys boiei at Parque Florestal do Itapetinga, São Paulo.

\begin{tabular}{lccc}
\hline \multicolumn{1}{c}{ Prey category } & $\begin{array}{c}\text { Percentage of total } \\
\text { volume }(\mathrm{N}=26)\end{array}$ & $\begin{array}{c}\text { Percentage of prey } \\
\text { number }(\mathrm{N}=38)\end{array}$ & $\begin{array}{c}\text { Percentage of } \\
\text { occurrence }(\mathrm{N}=38)\end{array}$ \\
\hline Coleoptera & 39.4 & 30.3 & 44.7 \\
Orthoptera & 25.0 & 25.0 & 42.1 \\
Araneae & 7.6 & 6.6 & 13.2 \\
Hemiptera & 5.3 & 2.6 & 5.3 \\
Insect larvae & 4.5 & 11.8 & 18.4 \\
Blattaria & 4.1 & 2.6 & 5.3 \\
Others * & 12.7 & 21.1 & 31.6 \\
\hline
\end{tabular}

*. Neuroptera, Vespidae, Formicidae, Anura, Isoptera, Phasmida, Oligochaeta, Gastropoda.

\section{DISCUSSION}

Ontogenetic shifts in prey size and type in frogs were reported in previous studies (e.g. WOOlBright \& STEWART 1987; LiMA \& MOREIRA 1993) and the correlations found indicate that this is also true for Proceratophrys boiei. It has been proposed that ontogenetic shifts in prey type may be a consequence of differences in available prey size (PENGILLEY 1971), since the mean size of individuals differs among arthropod orders (SCHOENER \& JANSEN 1968), or may reflect an effective 
change in prey selection by the frog (LIMA \& MOREIRA 1993). Sampling of the availability of prey would be necessary to evaluate the possible causes of the prey type shifts observed in $P$. boiei. Based on the type of prey taken, on their number per stomach and on some $P$. boiei features, such as crypticity and wide mouth, the species is more likely to be a sit and wait forager (see ToFT 1981, 1985).

ACKNOWLEDGMENTS. We thank to G. Machado for helping in the field work, C.E.P. de Souza for the identification of the arthropods and J. Shepherd for permission to use FITOPAC. I. Sazima, A.J. Cardoso and C.F.B. Haddad critically read the draft. A.T. de Souza helped in the statistical analysis. Two anonymous reviewers made useful comments on the draft. Grants by CNPq (A.A.G. and H.F. de M.) and CAPES (M.S.A. and K.G.F.).

\section{REFERENCES}

Christhian, K.A. 1982. Changes in the food niche during postmetamorphic ontogeny of the frog Pseudacris triseriata. Copeia 1982: 73-80.

Cochran, D.M. 1955. Frogs os Southeastern Brazil. U.S. Nat. Mus Bull. 206: $1-423$.

DE BRuyn, L., M. Kazadi \& J. Hulselmans. 1996. Diet of Xenopus fraseri (Anura, Pipidae). Jour. Herpetol. 30 (1): 82-85.

Duellman, W.E. \& L. TRUeB. Biology of Amphibians. New York, McGraw-Hill, $670 \mathrm{p}$.

Evans, M. \& M. LAMPo. 1996. Diet of Bufo marinus in Venezuela. Jour. Herpetol. 30 (1): 73-76.

LABANICK, G.M. 1976. Prey availability consumption and selection in the cricket frog, Acris crepitans (Amphibia, Anura, Hylidae). Jour. Herpetol. 10(4): 293-298.

LIMA, A.P. \& G. MoreIRA. 1993. Effects of prey size and foraging mode on the ontogenetic change in feeding niche of Colostethus stepheni (Anura: Dendrobatidae). Oecologia 95:93-102.

Manly, B.F.J. 1986. Multivariate Statistical Methods - A Primer. London, Chapman \& Hall, 159p.

PENGiLLEY, R.K. 1971. The food of some Australian anurans (Amphibia). J. Zool. Lond. 163: 93-103.

SCHOENER, T.W. \& D.H. JANSEN. 1968. Notes on environmental determinants of tropical versus temperate insect size patterns. Amer. Nat. 925: 207-224.

TOFT, C.A. 1981. Feeding ecology of Panamanian litter anurans: patterns in diet and foraging mode. Jour. Herpetol. 15: 139-144.

. 1985. Resource partitioning in amphibians and reptiles. Copeia 1985: $1-21$.

WoOLBRIGHT, L.L. \& M.M. STEWART. 1987. Foraging success of the tropical frog Eleutherodactylus coqui: the cost of calling. Copeia 1987: 69-75.

ZAR, J.H. 1984. Biostatistical Analisys. New Jersey, Prentice Hall, 718p.

Recebido em 16.I.1997; aceito em 19.V.1998 